\title{
FORMANDO PROFESSORES E TAMBÉM LEITORES: PRÁTICAS DE LETRAMENTO LITERÁRIO COM LICENCIANDOS EM PEDAGOGIA
}

\author{
Paulo Ailton Ferreira da Rosa Junior ${ }^{\mathrm{i}}$
}

\begin{abstract}
Resumo: Este artigo versa sobre uma experiência de estágio docente realizada no curso de Pedagogia da Universidade Federal de Pelotas, que teve como objetivo promover práticas de letramento literário baseadas em Cosson (2018a; 2018b). Esta ação visava contribuir na formação de professores que fossem, também, leitores de literatura preocupados em promover o ensino de leitura literária em suas aulas. Como metodologia, foi proposta a leitura guiada de três obras literárias brasileiras, discutidas em Círculos de Leitura e sobre as quais os alunos escreveram em Diários de Leitura. Fundamentado no vivenciado, concluiu-se que a fluência na prática da leitura literária é também precária entre discentes de cursos superiores e que o compromisso com o ensino dela deve se estender a esse nível.
\end{abstract}

Palavras-chave: Letramento literário; Ensino superior; Leitura; Literatura.

\section{TRAINING TEATCHERS AND ALSO READERS: PRACTICES OF LITERARY LITERACY WITH EDUCATION STUDENTS}

\begin{abstract}
This paper deals with an experience of teaching internship, held in the Pedagogy course of the Federal University of Pelotas, which aimed to promote literary literacy practices based on Cosson $(2018 \mathrm{a} ; 2018 \mathrm{~b})$. This action aimed to contribute to the training of teachers who were also literature readers concerned with promoting literary reading teaching in their classes. As a methodology, it was proposed the guided reading of three Brazilian literary works, discussed in Reading Circles and on which the students wrote in Reading Diaries. From the experience, it was concluded that fluency in the practice of literary reading is also precarious among students of higher education and that the commitment to teaching it should extend to this level.
\end{abstract}

Keywords: Literary literacy; Higher education; Reading; Literature.

\section{Introdução}

O presente artigo, resultado de uma experiência de estágio docente no ensino superior, realizada no segundo semestre do ano de 2018 por um então aluno de mestrado do Programa de Pós-graduação em Educação (PPGE), da Faculdade de Educação (FaE) vinculada à Universidade Federal de Pelotas (UFPEL), no Rio Grande do Sul. Ela transcorreu na disciplina optativa de "Educação e Literatura" ofertada, a priori, a alunos regularmente matriculados do segundo ao aberto distribuído sob os termos da Licença Creative Commons Atribuição Não ComercialCompartilha Igual (CC BY-NC-4.0), que permite uso, distribuição e reprodução para fins não comerciais, com a citação dos autores e da fonte original e sob a mesma licença 


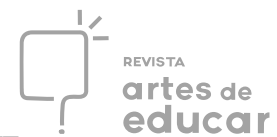

oitavo semestre do curso de Licenciatura em Pedagogia da referida instituição. Tal experiência se deu vindo ao encontro de anseios tanto do mestrando - enquanto professor licenciado em Letras pela Universidade Federal do Pampa, com especial interesse em ensino de literatura quanto da sua orientadora, professora adjunta da UFPEL, além de colaboradora do PPGE, atuando também como regente de disciplinas do primeiro semestre do curso de Pedagogia, em que vinha percebendo a defasagem dos alunos - futuros professores - no que tangia a práticas de leitura literária.

Essa percepção da professora não demorou a ser corroborada no âmbito desta experiência. "Eu nunca tinha lido um livro inteiro na vida", declarou, assim, uma das alunas da disciplina de "Educação e Literatura" em certo momento das primeiras atividades; confissão sintomática de um cenário comum à educação formal, mas, neste caso, à educação superior em especial: o da pouca familiaridade dos alunos de graduação com a leitura literária. Como já verificado por Meira (2014, p. 9), mesmo o ingressante em licenciaturas que trabalhem com literatura em seus currículos [...] quase nada leu de nossos romancistas ou poetas [...] o fato é que, até esse momento, com raras exceções, a literatura - pelo menos de maneira direta, isto é, mediante a leitura de romances, contos, poemas, etc. - não participou de sua formação intelectual e afetiva. Tal constatação tem como fonte a crise do ensino de literatura especificamente do ensino de leitura literária - na educação básica.

A escassez de propostas de ensino de língua e literatura centradas na leitura literária, principalmente na disciplina específica do ensino médio, que apesar das críticas à perspectiva historicista postulou-se tradicionalmente nela como perspectiva de ensino, e a posterior diluição no componente curricular de língua portuguesa das competências que deveria desenvolver, ratificada a partir das reformas propostas pela Base Nacional Comum Curricular (BNCC), vêm contribuindo fortemente para essa crise na formação de leitores literários. Como comentam Segabinazi e Silva (2015):

A dimensão dada ao perigo em que a literatura vem passando decorre da constatação de formação precária de leitores literários a partir do momento em que as aulas de literatura têm de tudo, menos literatura de fato, isto é, quando não se trabalha com os textos literários para além de nomenclaturas. [...] Concepções que reduzem a literatura à autossuficiência do livro didático enquanto instrumento para um trabalho estrutural da língua e que não pressuponha busca de sentido para o aluno sobre o que e como o texto diz o que diz são falhas e arcaizantes, mas infelizmente ainda muito comuns (p. 67-68).

Revista Interinstitucional Artes de Educar. Rio de Janeiro, V. 6, N.2- pág. 692-712 maio-agosto de 2020: "Bebês e crianças: cultura, linguagem e políticas" 


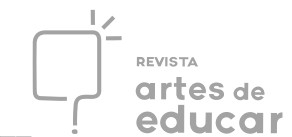

Dessa forma, não é surpresa que mesmo alunos - tanto ingressantes quanto veteranos de licenciaturas cujo trabalho com a leitura literária se faz primordial - como, neste caso, a pedagogia - não dominem a prática. Consequentemente, pesquisadores como Yunes (1995, p. 188) têm chegado à conclusão de que raríssimos professores gostam de ler e perguntam-se: como é possível a um professor ou a uma professora que não gosta de ler [...], que não sente prazer em desvendar os múltiplos sentidos possíveis de um texto, trabalhar para que seus alunos entrem na corrente da linguagem, na leitura e na escrita? (KRAMER \& JOBIM E SOUZA, 1996, p. 18). Nesse sentido, não trabalhar para reverter essa situação no âmbito da formação de novos professores é continuar alimentando um ciclo vicioso em que a literatura como arte e, portanto, passível de fruição em sua prática de leitura, acaba cada vez mais negligenciada na Educação.

Pensando nisso, planejou-se a proposta da disciplina "Educação e Literatura" em torno do que foi concebida por Cosson $(2018 ; 2018 b)$ como uma prática de letramento especifica à formação de leitores literários, o letramento literário: o processo de apropriação da literatura enquanto construção literária de sentidos (PAULINO \& COSSON, 2009, p. 67). Comumente estudado enquanto teoria em graduações como Pedagogia e Letras (dentre outras) e aplicado pelos profissionais dessas áreas apenas no ensino básico, ao qual se dirige enquanto proposta metodológica, neste texto, então, será apresentado como uma experiência possível de ser aplicada também ao ensino superior, visando ambas frentes: como formação de leitores literários, seu objetivo em essência, mas também como experimentação dessa prática na formação de mediadores de leitura literária que possam fazer uso desse subsídio metodológico em sua docência. Assim, as próximas páginas apresentam a fundamentação teórica norteadora, a descrição metodológica da experiência, uma avaliação reflexiva dos resultados e as considerações possíveis com base no que foi observado nesta prática.

\section{Pressupostos teóricos aplicados à proposta da disciplina}

A ementa da disciplina Educação e Literatura, já ministrada anteriormente por outros professores com base em seus aportes particulares, descrevia a proposta do componente curricular como a de oferecer subsídios teórico-metodológicos sobre as relações entre literatura e educação. Portanto, a escolha de planejá-la para a sua oferta no segundo semestre do ano de 2018 com suporte na ideia de letramento literário dialoga fortemente com o próprio intuito da 
prática que tem sua inserção em uma compreensão de educação para além daquela escolarizada, buscando

formar uma comunidade de leitores que, como toda comunidade, saiba reconhecer os laços que unem seus membros no espaço e no tempo. Uma comunidade que se constrói na sala de aula, mas que vai além da escola, pois fornece a cada aluno e ao conjunto deles uma maneira própria de ver e viver o mundo (COSSON, 2018, p. 12).

Assim, fazendo uso das acepções que compreendem o termo "letramento" -empréstimo da tradução linguística e conceitual feita por Soares (1998) - esta proposta entende a leitura literária não apenas como um conteúdo a ser ensinado pela escola, mas como uma prática social que perpassa a escola, que mesmo fazendo parte de suas responsabilidades integra a educação em um âmbito mais abrangente que o formal. A leitura literária configura-se, nesse viés, como uma competência humana que ajuda a elaborar e resolver questões da vida cotidiana, social e particular, através do domínio da linguagem, pois, nas palavras do autor, é no exercício da leitura dos textos literários que se desvela a arbitrariedade das regras impostas pelos discursos padronizados da sociedade letrada e se constrói um modo próprio de se fazer dono da linguagem que, sendo minha, é também de todos (COSSON, 2018, p. 15). Em outras palavras, a literatura forma para a autonomia do ser e estar para o mundo.

Acontece que tal caráter emancipatório é habitualmente ignorado pelo domínio comum. Em geral, imagina-se que a literatura opere na função formadora da transmissão de conhecimentos e valores. Nesse sentido, Candido (2002, p. 84) alerta que a sua função educativa é muito mais complexa do que supõe um ponto de vista estritamente pedagógico [...] Longe de ser um apêndice da instrução moral e cívica [...], ela age com o impacto indiscriminado da própria vida e educa como ela, - com altos e baixos, luzes e sombras. Essa constatação pode explicar porque, então, os modos de pensar que justificam muitas das práticas correntes do ensino de literatura e leitura literária pautados em um viés apenas estruturalista têm falhado em formar leitores literários.

Geralmente, atribuiu-se também à leitura literária o desenvolvimento da erudição do bem escrever e bem falar e de uma inteligência técnica e científica. Entretanto, enquanto trabalho linguístico, ela atua mais profundamente: quer percebamos claramente ou não, o caráter de coisa organizada da obra literária torna-se um fator que nos deixa mais capazes de ordenar a nossa própria mente e sentimentos; e, em consequência, mais capazes de organizar a visão que temos do mundo (CANDIDO, 2011, p. 179). 


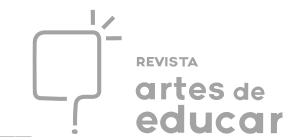

Assim, tirando as palavras do nada e ordenando-as em um todo articulado, ela organiza o caos interior e exterior ao ser humano atuando no processo que chama de "humanização", aquele que confirma no homem a sua quota de humanidade. O que deveria fazer da literatura um direito assegurado a todo ser humano, pois, tomando sua função em conta, ela equivaleria a outras necessidades básicas que contribuem ao nosso equilíbrio físico e psíquico.

Para explorar, então, tamanha potencialidade, estabeleceram-se três objetivos específicos a esta proposta da disciplina Educação e Literatura. O primeiro projetava ofertar a leitura de três obras literárias brasileiras, sendo o eixo principal da disciplina, a promoção de práticas de leitura literária, da oportunidade do encontro entre leitores em potencial para livros em específico. Cosson (2018b, p. 161) "Bom para discutir é o texto que desperta, inquieta e demanda uma posição do leitor. Nesse sentido pensamos em ofertar títulos brasileiros - tendo em vista o desprestígio da literatura brasileira tanto no mercado livreiro popular quanto no senso comum de muitos leitores - parte do que Candido (2011) chama de "literatura social", aquela que leva-nos a conhecer os sentimentos e a sociedade, ajudando-nos a tomar posição em face deles”, são leituras "que partem de uma análise do universo social e procuram retificar as suas iniquidades" (CANDIDO, 2011, p. 183), obras que, assim, pudessem mobilizá-los.

O segundo objetivo específico postulado foi o de incitar a reflexão crítica sobre a leitura dessas obras através de escritas pessoais; para cumprir tal meta foi eleito como recurso o diário de leitura, não apenas uma transposição do diário íntimo para o ambiente escolar, mas uma reflexão que o leitor faz sobre o texto e o próprio ato de ler com recursos expositivos que passam pela descrição e pela explicação [...] um registro das impressões do leitor durante a leitura do livro (COSSON, 2018, p. 122). O terceiro objetivo específico foi pensado, assim, como forma de aprofundar a experiência de leitura e reflexão acerca dos textos com o ato de promover momentos de socialização de leitura dessas obras. Para isso, elegeu-se a prática do círculo de leitura, definido por Cosson (2018b) como um grupo de pessoas que se reúnem em uma série de encontros para discutir a leitura de uma obra [...] essencialmente o compartilhamento organizado de uma obra dentro de uma comunidade de leitores que se constitui para tal fim (COSSON, 2018b, p. 157-158).

Os dois objetivos específicos elencados por último vêm ao encontro do fundamento de que ler implica troca de sentidos não só entre o escritor e o leitor, mas também com a sociedade onde ambos estão localizados, pois os sentidos são resultado de compartilhamentos de visões do mundo entre os homens no tempo e espaço (COSSON, 2018, p. 27). Assim, leitor literário e literatura só tem seu encontro concretizado na prática de uma leitura particular, ou seja, situada 


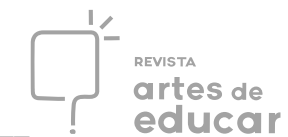

em um determinado momento e um determinado lugar, que serve como ponte entre eles. Mas a particularidade dessa leitura ergue apenas as vigas dessa ponte. É a troca de impressões com outros, o compartilhamento dessa apreciação pessoal e a recepção de outras interpretações, que termina de construí-la. Colomer (2007) ressalta que:

Compartilhar as obras com outras pessoas é importante porque torna possível beneficiar-se da competência dos outros para construir o sentido e obter o prazer de entender mais e melhor os livros. Também porque permite experimentar a literatura em sua dimensão socializadora, fazendo com que a pessoa se sinta parte de uma comunidade de leitores com referências e cumplicidades mútuas (p. 134).

Ainda, a autora ainda reforça que as atividades de compartilhar são as que melhor respondem a esse antigo objetivo de 'formar o gosto' (COLOMER, 2007, p. 135), motivação principal da disciplina que busca, também, em Todorov (2014) sustentação para pensar a importância deste "tomar gosto" pela leitura literária, quando o autor diz que a obra literária produz um tremor de sentidos, abala nosso aparelho de interpretação simbólica, desperta nossa capacidade de associação e provoca movimentos cujas ondas de choque prosseguem por muito tempo depois do contato inicial (TODOROV, 2014, p. 78), atuando, então, em um nível de formação que apenas a arte consegue tocar e que vem sendo negligenciado pelas práticas educacionais formais.

Por fim, da mesma forma que Cosson (2018; 2018b) admite não estar inventando a roda com seu letramento literário, também entendeu-se para o planejamento da disciplina Educação e Literatura que a aplicação dos preceitos compilados por ele e a sua reinvenção para o ensino superior fazem parte do movimento contínuo que é pensar o ensino de leitura literária como $o$ processo de formação de um leitor capaz de dialogar no tempo e no espaço com sua cultura, identificando, adaptando ou construindo um lugar para si mesmo (COSSON, 2018, p. 120) e que, neste caso, ao final dela, esteja tanto apropriado da prática de leitura quanto consciente da importância formadora da literatura mediante a fruição da mesma e apto a transpor as experiências vividas também para a sua prática.

\section{Descrevendo materiais, métodos e a recepção da proposta}

Antes de pormenorizar a prática e sua recepção, ressaltam-se alguns pontos.

Revista Interinstitucional Artes de Educar. Rio de Janeiro, V. 6, N.2-pág. 692-712 maio-agosto de 2020: "Bebês e crianças: cultura, linguagem e políticas"

DOI: $10.12957 /$ riae.2020.44629 
A experiência de estágio orientado na disciplina Educação e Literatura transcorreu no contexto de um semestre atípico, com um calendário repleto de eventos acadêmicos e feriados a darem-se às sextas-feiras, exatamente no dia designado para o componente. Isso fez com que o número de encontros possíveis com a turma somasse o total de treze, contra uma quantia usual que vai de quinze a dezoito ao longo do semestre. Onze dos encontros realizaram-se presencialmente e dois ficaram reservados para serem usados pelos alunos para dedicarem-se à leitura das obras propostas: "O Meu Pé de Laranja Lima", de José Mauro de Vasconselos; "Capitães de Areia", de Jorge Amado; e "Quarto de Despejo", de Carolina Maria de Jesus. A regência configurou-se como compartilhada, ou seja, algumas aulas tiveram a condução do estagiário em companhia de sua orientadora. Com dezoito alunos regularmente matriculados no componente, a disciplina teve como assíduos doze deles, oriundos dos mais diferentes semestres do curso de Pedagogia, e foi realizada no turno da noite, das 19h30min às 21h30min, entre agosto e dezembro de 2018, no espaço físico do grupo Hisales ${ }^{\mathrm{ii}}$, parceiro da ação. O quadro a seguir esquematiza o cronograma de aulas e atividades da disciplina.

\section{QUADRO 1. CRONOGRAMA DE AULAS DA DISCIPLINA "EDUCAÇÃO E LITERATURA"}

\begin{tabular}{|l|l|}
\hline DATA & ATIVIDADE \\
\hline $17 / 8$ & Apresentação da disciplina. \\
\hline $24 / 8$ & Participação em noite cultural de evento. \\
\hline $31 / 8$ & $\begin{array}{l}\text { Motivação à leitura da obra "O Meu Pé de Laranja Lima" e início da escrita nos } \\
\text { diários. }\end{array}$ \\
\hline $07 / 9$ & Feriado do Dia da Independência. \\
\hline $14 / 9$ & Reservado para leitura da obra. \\
\hline $21 / 9$ & Discussão de texto teórico. \\
\hline $28 / 9$ & Círculo de leitura de "O Meu Pé de Laranja Lima". \\
\hline $05 / 10$ & Motivação à leitura da obra "Capitães da Areia" e escrita nos diários. \\
\hline $12 / 10$ & Feriado do Dia da Padroeira. \\
\hline $19 / 10$ & Discussão de texto teórico. \\
\hline $26 / 10$ & Participação em evento. \\
\hline $02 / 11$ & Feriado do Dia de Finados. \\
\hline $09 / 11$ & Círculo de leitura de "Capitães da Areia". \\
\hline $16 / 11$ & Motivação à leitura da obra "Quarto de Despejo" e escrita nos diários. \\
\hline $23 / 11$ & Reservado para leitura da obra. \\
\hline $30 / 11$ & Discussão de texto teórico. \\
\hline $07 / 12$ & Círculo de leitura da obra “Quarto de Despejo". \\
\hline $14 / 12$ & Socialização dos diários de leitura, avaliação e encerramento da disciplina. \\
\hline
\end{tabular}

Fonte: Plano de ensino da disciplina, produzido pelo autor.

Revista Interinstitucional Artes de Educar. Rio de Janeiro, V. 6, N.2-pág. 692-712 maio-agosto de 2020: "Bebês e crianças: cultura, linguagem e políticas" 
O primeiro encontro, em que foi apresentado o plano de ensino da disciplina, pegou muitos dos alunos de surpresa com a ideia de preconizar a fruição de leituras literárias, apresentando o conceito de letramento literário, e não propor avaliações típicas, como a escrita de artigos ou a aplicação de provas. Os mecanismos formais de avaliação seriam, então, as escritas dos diários de leitura e as participações orais nos círculos de leitura, e as leituras obrigatórias essenciais seriam, então, as das obras literárias selecionadas, sendo as dos textos teóricos - pois toda disciplina de curso superior requer reflexão teórica - feitas diretamente em aula.

Houve bastante curiosidade sobre o advento do diário de leitura e, então, para exemplificar o que seria um, utilizou-se de acervo específico do grupo Hisales, com exemplares de diários de leitura de alunos do ensino médio utilizados em tese de uma pesquisadora do grupo. Por meio do manejo desses materiais, a turma descobriu que a pessoalidade evocada pelo termo diário poderia ser levada a sério mesmo este sendo um mecanismo de avaliação formal da disciplina. A maioria dos diários do acervo utilizava de cadernos pequenos que eram decorados pelos seus autores, havendo alguns também confeccionados artesanalmente com folhas de ofício costuradas ou grampeadas em forma de livreto. Assim, os alunos já tiveram ideias sobre como construir os seus. Solicitou-se que todos começassem os seus diários escrevendo, pelo menos, um parágrafo sobre si mesmo e suas experiências anteriores de leitura, um breve resumo da sua relação com a literatura até então.

Para o que se seguiria ao primeiro encontro, organizou-se a metodologia em três módulos de quatro aulas, cada módulo correspondente à exploração de uma das obras literárias propostas, cada aula correspondente a um estágio desta exploração: uma primeira aula introdutória, visando incitar motivação para a leitura - em que se apresentava a obra, seu autor ou autora, seu contexto de produção e recepção, edições ao longo do tempo e a edição que seria utilizada e iniciava-se a escrita nos diários -, uma aula reservada para leitura em casa, uma aula de discussão de algum texto teórico - não por acaso os mesmos sobre os quais discorreu-se na sessão anterior deste relato - e uma aula dedicada à realização do círculo de leitura da obra em questão. Cada módulo foi planejado para que os alunos tivessem, pelo menos, o tempo de um mês para realizar a leitura de cada livro.

Para potencializar a experiência e o contato com a literatura brasileira em suas mais variadas formas, toda aula começava com a leitura em voz alta, por parte do professor estagiário, de algum texto literário de menor fôlego que os romances propostos - conto, crônica ou poema acompanhada pelos alunos em suas cópias impressas daquele texto e sobre as quais eram Revista Interinstitucional Artes de Educar. Rio de Janeiro, V. 6, N.2- pág. 692-712 maio-agosto de 2020: "Bebês e crianças: cultura, linguagem e políticas"

DOI: 10.12957/riae.2020.44629 
dedicados alguns momentos de apreciação. Foram lidos contos como "Canibal", de Moacyr Scliar, "Um espinho de marfim", de Marina Colasanti, "Para uma avenca partindo", de Caio Fernando Abreu e "Felicidade Clandestina", de Clarice Lispector, entre vários outros; crônicas de Luis Fernando Veríssimo, Fernando Sabino e Fabrício Carpinejar, e poemas de Paulo Leminski, Conceição Evaristo e Carlos Drummond de Andrade.

O primeiro módulo da metodologia abarcou leitura e reflexão acerca do romance "O Meu Pé de Laranja Lima”, de José Mauro de Vasconselos. Na aula introdutória, o passo a passo visava incitar motivação para a leitura; o primeiro movimento consistiu sempre em acionar os conhecimentos prévios dos alunos sobre o título em questão. Muitos lembraram da novela televisiva baseada no livro, alguns falaram em familiares que haviam recomendado a leitura, os demais não conheciam e, em totalidade, a turma não havia lido o romance até então. Feita uma explanação sobre obra, autor, contexto de produção e sua recepção tanto pela crítica quanto pelos leitores da época e ao longo do tempo, exibiu-se um clipe de cenas das três adaptações em telenovela e das duas em longa metragem, além de apresentar a edição mais recente, lançada em comemoração aos 50 anos da primeira publicação, representada na figura a seguir.

\section{Figura 1: Capa da edição sugerida para a leitura de "O Meu Pé de Laranja Lima"}

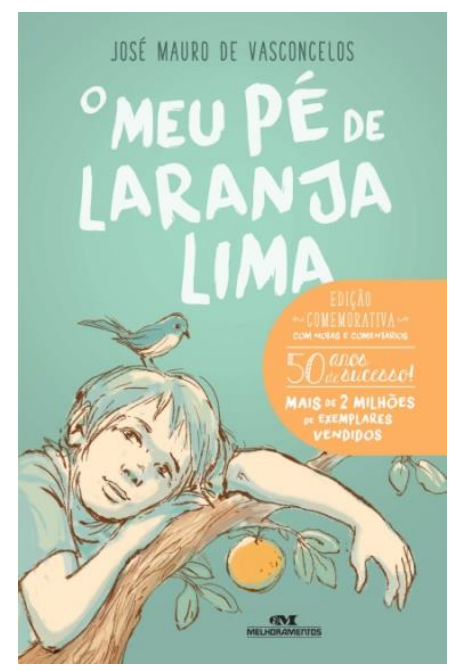

Fonte: Google Imagens.

Ainda que essa edição estivesse sendo utilizada pelos professores como base, os alunos foram deixados livres para ler a obra em qualquer outra edição que estivesse melhor ao alcance deles. Surgiram pelo menos três edições diferentes, datadas dos anos 1970, 2000 e 2010, cujas capas estão reproduzidas a seguir.

Revista Interinstitucional Artes de Educar. Rio de Janeiro, V. 6, N.2- pág. 692-712 maio-agosto de 2020: "Bebês e crianças: cultura, linguagem e políticas"

DOI: 10.12957/riae.2020.44629 


\section{Figura 2: Capas das edições de “O Meu Pé de Laranja Lima” lidas pelos alunos e alunas}
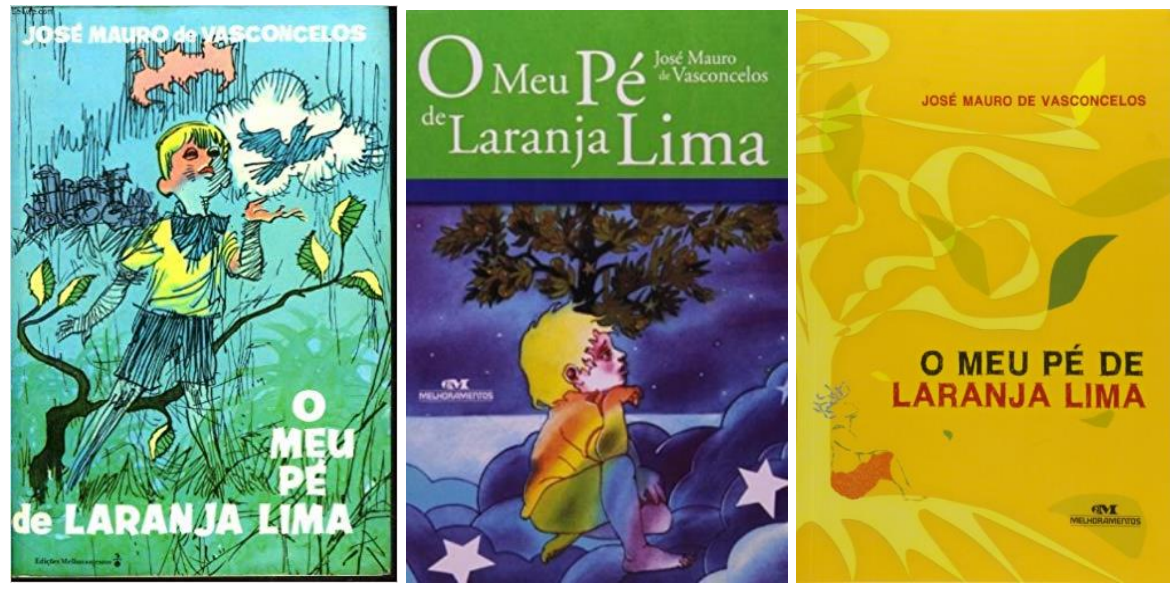

Fonte: Google Imagens.

Para continuar a escrita dos diários de leitura, a turma foi solicitada a discorrer sobre "o que eu sei sobre o livro ‘O Meu Pé de Laranja Lima' e o que eu espero dessa leitura?’. Essa foi a primeira diretriz do trabalho de escrita especificamente relacionado à primeira obra do cronograma de leitura. Além disso, assim que tivessem suas edições em mãos, os alunos deveriam contar como as haviam conseguido e descrever a sua materialidade, atentando também para os dados bibliográficos. Essa fase de escrita foi chamada de "Antes da leitura", sucedida pelo "Durante a leitura", quando os alunos poderiam escrever livremente sobre sua experiência de leitura do livro: anotando partes que lhes chamassem a atenção, comentando acontecimentos, expressando-se sobre o que sentiam, o que lhes incomodava, o que lhes confortava, se estava sendo uma leitura fácil/agradável/fluída ou difícil/incômoda/truncada, etc.

Para o círculo de leitura de "O Meu Pé de Laranja Lima", uma recomendação importante: a leitura do livro precisaria estar completa, afinal, não faria sentido debater uma obra que não tenha sido efetivamente finalizada por eles. Para a realização da atividade, o espaço onde se davam os encontros foi reorganizado sem mesas, apenas cadeiras dispostas formando um grande círculo. Devido à recomendação assinalada no início do parágrafo, alguns alunos não apareceram para a atividade. Como anfitriões, os professores foram os primeiros a contribuir com o círculo, Revista Interinstitucional Artes de Educar. Rio de Janeiro, V. 6, N.2-pág. 692-712 maio-agosto de 2020: "Bebês e crianças: cultura, linguagem e políticas" 
oferecendo suas impressões sobre o livro a partir do seguinte postulado escrito no quadro: “Como foi a experiência de leitura de 'O Meu Pé de Laranja Lima'? Fale sobre as dificuldades, as facilidades, os momentos que marcaram na narrativa, personagens preferidos e o que essa obra deixou para você como aprendizado", de modo que os alunos soubessem como proceder. Em suma, a fala individual no círculo poderia inspirar-se nas reflexões escritas nos diários.

Esse primeiro círculo de leitura foi também o mais intenso de todos, pois a história do menino Zezé contada em “O Meu Pé de Laranja Lima”, com alto teor autobiográfico empregado pelo autor, tocou profundamente os leitores da turma por centrar-se no tema da carência na infância, chegando a levar alguns às lágrimas durante seu testemunho de leitura. Um por um os alunos ofereceram suas impressões, sempre bastante comprometidos tanto em contribuir quanto em ouvir as contribuições dos demais. Deixou-se muito claro durante a atividade que não há lugar para a ideia de certo ou errado em uma proposta como essa, apenas a de diferença entre interpretações e opiniões, e que o que interessava à avaliação era entender o quanto o livro havia lhes tocado, ou não, e por quê. Importava, assim, terem cumprido a leitura e conseguido refletir sobre ela enquanto experiência estética. Em geral, a turma demonstrou bastante afeição pelo romance e alguns até buscaram pela continuação da história de Zezé em outro livro do autor, "Vamos Aquecer o Sol".

Terminada a rodada de participações no círculo, a turma recebeu, então, direcionamentos para o que foi chamado de "Depois da leitura", a parte escrita do diário que encerrava as atividades do módulo de leitura em questão. Nesta parte, os alunos precisavam dissertar brevemente, em teor de conclusão, sobre algum tema transversal da obra lida selecionado pelo professor estagiário. No caso de "O Meu Pé de Laranja Lima", foram escolhidos os temas da violência e da imaginação, fortemente presentes no livro.

O segundo módulo da disciplina teve "Capitães da Areia", de Jorge Amado, como romance selecionado para a leitura. A exemplo do primeiro módulo, a aula introdutória à leitura da obra em questão começou acionando os conhecimentos prévios dos alunos sobre o livro e o autor. O título era desconhecido por quase todos, à exceção de um aluno, mas o nome de Jorge Amado suscitou alguns reconhecimentos, principalmente por conta dos trabalhos de adaptação para o cinema e a televisão das narrativas de sua autoria. Assim, além de apresentar o autor e o contexto de produção e recepção do livro, também foram relembrados, por meio da projeção de fotos e vídeos, os diversos títulos populares concebidos por Amado que foram transformados em filmes, telenovelas e minisséries, como "Gabriela, Cravo e Canela", "Dona Flor e Seus Dois 
Maridos" e "Tieta do Agreste", bem como apresentada a edição de "Capitães da Areia" que os professores utilizariam para a leitura como sugestão.

Figura 3: Capa da edição sugerida para a leitura de "Capitães da Areia".

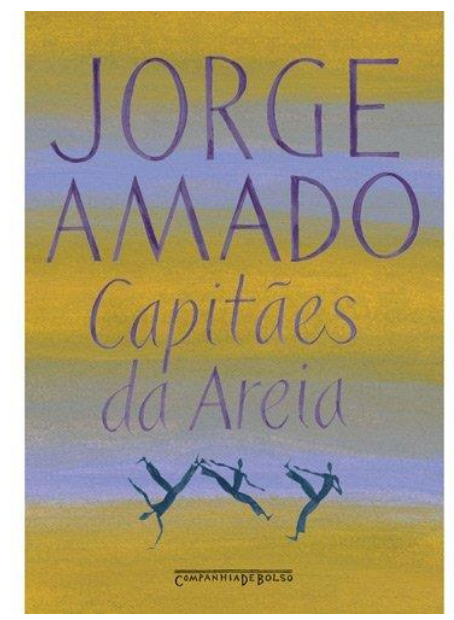

Fonte: site da editora Companhia de Bolso.

O próximo passo do segundo módulo, tal qual como o do primeiro, foi a primeira escrita no diário. Mais uma vez o "Antes da leitura", em que os alunos deveriam discorrer sobre os conhecimentos prévios acionados sobre autor e obra e as suas expectativas para "Capitães da Areia”. Passada a aula reservada para leitura, quando na ocasião da discussão do próximo texto teórico, tivemos um vislumbre das outras edições, além da sugerida, que estavam sendo lidas pelos alunos.

Figura 4: Capas das outras edições de "Capitães da Areia" utilizadas pelos alunos 


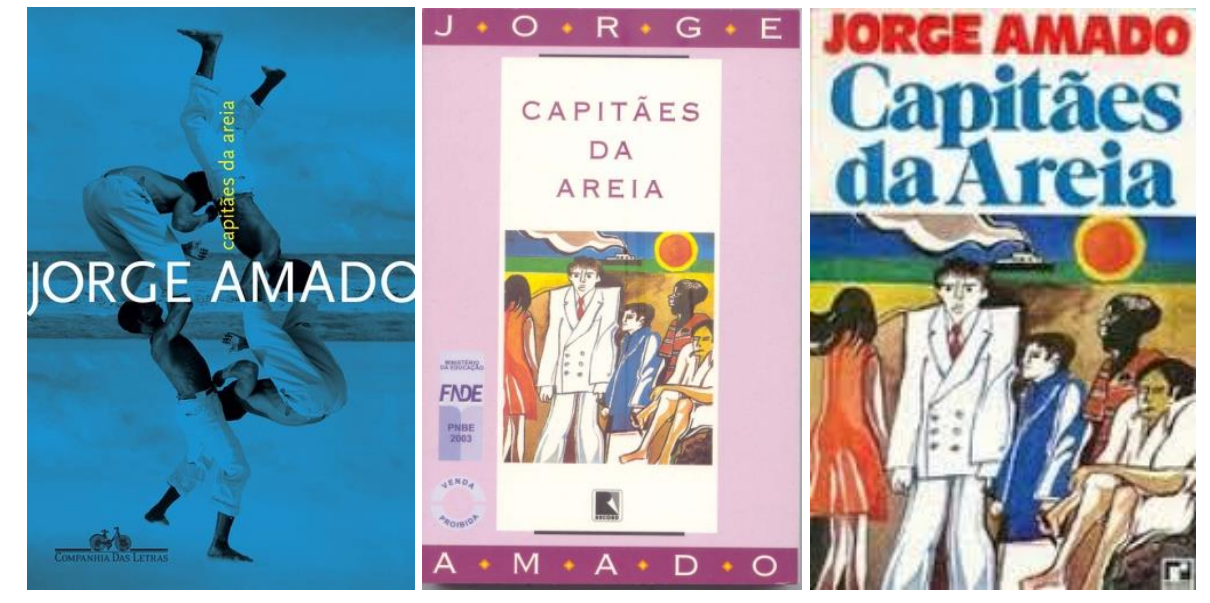

Fonte: google imagens.

Grande parte fez a leitura na mesma edição utilizada pelos professores, visto que estava ofertada por preço acessível em uma loja virtual. Respectivamente, como aparecem na figura 4, as outras edições utilizadas pelos alunos foram uma que o aluno já possuía, uma conseguida na biblioteca de uma escola municipal e a terceira, em maior quantidade que as outras duas, em sebos.

O círculo de leitura de "Capitães da Areia" foi o mais vazio. A recomendação de que a leitura precisava estar finalizada para o bom aproveitamento da atividade se repetiu. Quando perguntados sobre a ausência dos colegas, os alunos participantes compartilharam alguns testemunhos de que a leitura do livro estava sendo difícil para a maioria. Assim, dois dos presentes confessaram ter desistido do livro e assistido ao filme, tentando compensar. As diretrizes para guiar os depoimentos e discussões dentro do círculo eram as mesmas da sua realização anterior: "Como foi a experiência de leitura de 'Capitães de Areia'? Fale sobre as dificuldades, as facilidades, os momentos que marcaram na narrativa, personagens preferidos e o que essa obra deixou para você como aprendizado". Durante os testemunhos individuais poucos declararam ter gostado do livro, havendo basicamente incômodo com a linguagem empregada na narrativa e com o teor dela, considerada como um "mau exemplo". Houve também quem demonstrasse dificuldade em compreender que, mesmo usando de recursos como notícias de jornal e tratando de temas tão duros - como os da vida marginalizada -, diferentemente de "O Meu Pé de Laranja Lima”, que possui traços autobiográficos, esta se tratava de uma obra de ficção.

Torna-se importante ressaltar que a dinâmica do círculo de leitura, apesar de ter como foco o relato individual das impressões de leitura do livro, movia-se do particular para o coletivo 
na medida em que, com base no compartilhamento de impressões individuais e pessoais dos alunos, os professores, enquanto mediadores da atividade, buscavam incitar o diálogo, convidando os demais a posicionarem-se, também, sobre "esta" ou "aquela" questão tocada pelo declarante do momento, explorando o caráter interacionista da proposta. Estar no círculo de leitura não é apenas discorrer sobre a sua experiência com o livro e ouvir a dos outros, mas debater essas experiências e, quem sabe assim, construir novas leituras possíveis, em um movimento ininterrupto de interpretação daquela narrativa.

Finalizada a atividade, o próximo passo do módulo consistia na escrita do "Depois da Leitura" nos diários, reflexões pós-conclusão da obra com dois temas norteadores selecionados pelo professor estagiário: a sexualidade e a religiosidade. Provavelmente pelas dificuldades encontradas na leitura da narrativa, os alunos demonstraram também dificuldade em desenvolver suas escritas sobre os tópicos.

O terceiro e último módulo da disciplina trazia para leitura, discussão e escrita reflexiva a obra "Quarto de Despejo", autoria de Carolina Maria de Jesus. Desta vez, uma construção literária completamente autobiográfica. Ao buscar pelos conhecimentos prévios da turma sobre autora e obra, nenhum aluno demonstrou reconhecer uma ou outra. Assim, começou-se a construir a motivação para a leitura perguntando-lhes sobre o que o título "Quarto de Despejo" sugeria, levantando hipóteses.

A seguir, a aula introdutória apostou em explorar a figura da autora. Foram lidas reportagens sobre a trajetória de Carolina de Jesus que construíam quase um personagem mítico em cima dela e contrapostas com o vídeo de uma entrevista de sua filha, pelas palavras da qual Carolina surgia muito mais humanizada ou próxima de uma pessoa de carne e osso. A história da catadora de lixo que virou autora de best-seller causou grande interesse na turma, que também foi introduzida à HQ "Carolina", graphic novel que retrata a trajetória da escritora, essa constando apenas como "dica de leitura". Vale ressaltar que tanto a HQ sugerida quanto a edição utilizada pelos professores para a leitura obrigatória da disciplina fazem parte do PNLD literário das escolas.

\section{Figura 5: Capas da HQ "Carolina", de João Pinheiro da Silva e Sirlene Barbosa e de "Quarto de Despejo"}




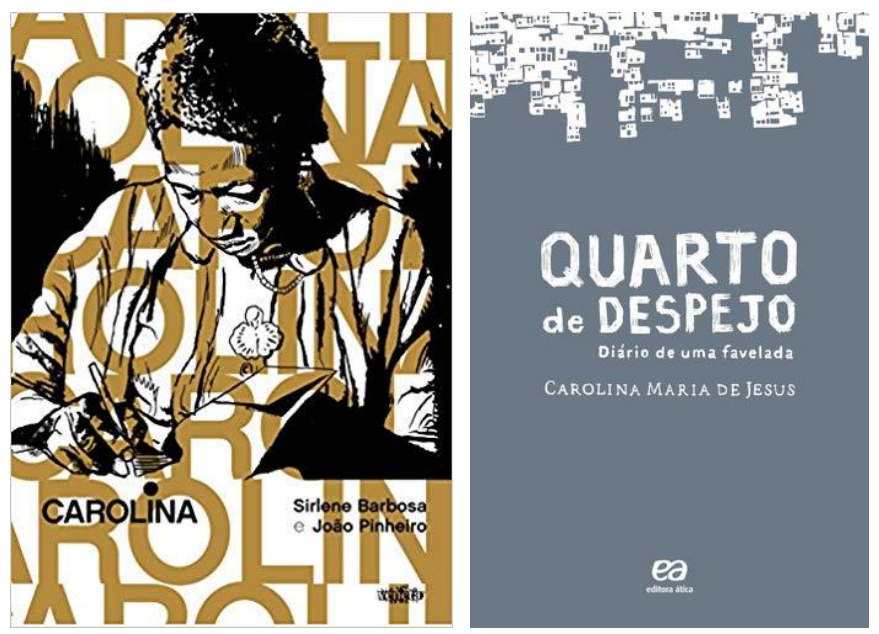

Fonte: Google Imagens.

Além da edição apresentada pelos professores, duas outras também figuraram entre aquelas que circularam entre os alunos: uma bastante antiga, conseguida em um sebo, sem a folha de dados bibliográficos e outra de 2001 comprada em certa quantidade pela turma.

Figura 6. Capas das duas edições citadas anteriormente, respectivamente
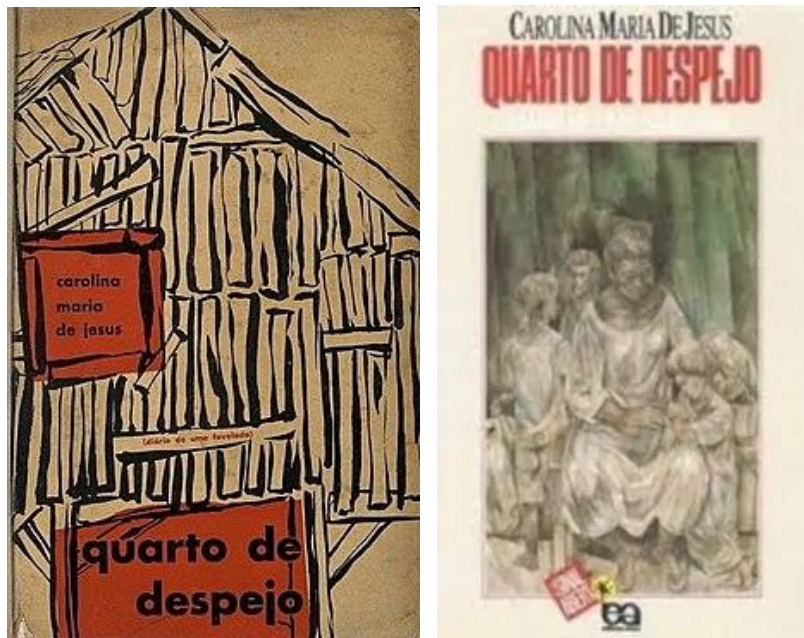

Fonte: Google Imagens.

O círculo de leitura da obra, guiado pela mesma questão direcionadora que os anteriores, revelou que os alunos, em sua maioria, leram "Quarto de Despejo" pulando trechos. Sintomático de quanto o texto, apesar das questões mobilizadoras que suscitou à turma, não prendeu tanto o grupo. A turma ressaltou, novamente, desconforto com a prosa da obra, desta vez por soar muito Revista Interinstitucional Artes de Educar. Rio de Janeiro, V. 6, N.2-pág. 692-712 maio-agosto de 2020: "Bebês e crianças: cultura, linguagem e políticas" 
- nas palavras deles - "cheia de erros", o extremo oposto de "Capitães da Areia" que era também nas palavras deles - "muito enfeitada". Os alunos confessaram, também, que sentiram a obra muito repetitiva, sendo o dia a dia descrito nela quase sempre igual, o que fazia com que decidissem pular páginas em busca de algum relato mais substancial por parte da autora. Outro motivo oferecido pelos leitores do círculo para essa prática de leitura incompleta do texto foi a demanda coincidir com as demais do fim do semestre. Afora isso, os testemunhos de leitura concordaram na opinião de que a obra permanecia extremamente atual, mesmo datando dos anos 1960, e na importância de passar adiante essa leitura, de não deixá-la cair no esquecimento e de retornar a ela "com mais calma e tempo".

Concluídos os compartilhamentos de leitura, a turma recebeu o direcionamento do último "Depois da leitura" para os diários: dissertar, em termos de conclusão da obra, sobre o tema dos direitos humanos no contexto do que ela narra. Para além, em termos de fechamento do diário, os alunos receberam como tarefa para casa a construção de uma página final, que deveria contemplar uma escrita de cunho avaliativo sobre a experiência da atividade de manter um diário de leitura e de cumprir um cronograma de leituras literárias durante o semestre como parte da formação docente, buscando pensar, também, em como isso impactaria, a partir de então, as suas concepções de ensino de leitura literária em suas práticas vindouras.

A aula derradeira da disciplina ocorreu nos moldes do círculo de leitura, mas com vistas a socializar os diários - a serem entregues naquela data. A intenção era dialogar sobre os mesmos temas da escrita de fechamento dos diários. Os alunos avaliaram que as tarefas de leitura das obras, discussão oral e escrita reflexiva sobre elas, exigiram tanto deles quanto outros mecanismos de avaliação mais tradicionais como as provas, seminários e artigos; que nem sempre, ou quase nunca, foi fácil escrever sobre o que liam ou mesmo efetuar essas leituras, sempre atrasadas ou cumpridas em cima da hora, e que apesar de outros aspectos, o principal motivo disso residia na compreensão deles de que não mantinham, até então, práticas regulares de leitura literária.

\section{Refletindo sobre os resultados}

Ao tomar como compromisso o ensino da leitura literária é preciso ter muito claro que o letramento literário não se trata de uma fórmula mágica que vai transformar os alunos e alunas em leitores proficientes de textos de literatura da noite para o dia. Formar leitores literários 
significa formar um gosto pessoal e individual e que jamais se constituirá como algo imutável e, exatamente por isso, o perfil do leitor literário é algo que se constrói apenas com o passar do tempo, com o exercício de práticas de leitura que tanto agradem quanto desagradem, pois também com a sensação do desconforto eu descubro o que me conforta. A prática do letramento literário em sala de aula é apenas um dentre tantos outros movimentos - inclusive aqueles que repelem o gosto pela leitura literária - desse eterno jogo de cabo de guerra que é o manejo dos bens culturais, para alguns um direito de todos, para outros um direito de poucos. Assim, afirmar aqui que a turma encerrou a disciplina com um bom saldo de leitores literários formados é uma utopia impensável. Entretanto, é possível ressaltar alguns ganhos, refletir sobre alguns fracassos, e, assim, tecer autocríticas que ajudem não apenas a pensar as próximas práticas, mas a guiar também aquelas de quem tenha buscado luz neste texto.

Primeiramente ressalta-se que, para alunos e alunas componentes de uma turma que declarou não possuir práticas regulares de leitura literária, os doze assíduos da disciplina terem lido pelo menos partes de três romances ao longo dos quatro meses em que as atividades transcorreram, já é um ganho. Para mais, o esforço coletivo em conseguir as obras - todos possuíam suas próprias cópias, fossem elas físicas ou digitais - e o fato de todos terem algo a dizer sobre a leitura delas, inclusive relacionando-as, provando que conseguiam se posicionar com relação ao que leram e começaram a construir um diálogo com a arte literária, são também pontos a serem valorizados como conquistas da experiência. São sintomas de que os alunos não passaram incólumes pelo encontro com os livros propostos para a leitura. Casos pontuais como o da aluna que nunca havia lido um livro inteiro até então - declaração reproduzida na introdução deste texto -, dos dois alunos que buscaram pela continuação de "O Meu Pé de Laranja Lima", do aluno que finalmente leu o seu exemplar guardado há sete anos de "Capitães da Areia" e achou que perdeu tempo em não ter lido antes ou da aluna que emprestou "Quarto de Despejo" para a mãe ler porque ela achou curioso a filha estar sempre com ele em mãos, também merecem ser reconhecidos.

Entretanto, a negação à autonomia dos alunos e alunas em escolher as obras que gostariam de ler pode ter sido um ponto falho no planejamento e aplicação desta experiência com letramento literário, algo que pode ter contribuído para que nem todas as leituras tenham sido feitas em sua completude. É possível que, para melhor aproveitamento da proposta, a ideia de disponibilizar uma lista de livros para que os alunos escolhessem, dentre eles, as obras que gostariam de ler, fosse mais eficiente. Bem como, é possível, também, que propor três obras para a leitura não tenha sido o ideal, levando a considerar a hipótese de que duas obras poderiam 
melhor se encaixar no tempo do semestre e possibilitar discussões em maior profundidade sobre cada uma.

\section{Conclusão}

Com fundamento no que foi vivenciado e, então, resumido nesse relato, é possível tecer algumas considerações. A primeira delas diz respeito à relação dos alunos e alunas com a literatura que, de fato, em geral, demonstrou-se precária. Eles manifestaram dificuldades com a linguagem das obras escolhidas, às vezes achando os textos muito aquém das suas habilidades com a norma culta, às vezes sem compreender que a aplicação de uma norma em desprestígio é um recurso literário da obra. No mesmo sentido, tiveram problemas em reconhecer outros artifícios utilizados na composição literária como a mescla de gêneros textuais e pessoas do discurso na tessitura da narrativa; tiveram, também, dificuldade em acompanhar o fôlego de leitura exigido, bem como em desvincular os textos literários de uma obrigação com a formação moral - dentro dos seus preceitos - e técnica. Todos esses aspectos denotam que o contato com textos literários variados e concepções de literatura fora do domínio comum, na trajetória destes estudantes, foi disperso.

Tendo em vista essa primeira constatação, entendeu-se que a proficiência na leitura literária faz parte, então, não apenas das competências a serem desenvolvidas na formação básica, mas também na formação do docente que lide com ensino de linguagens, tanto quanto uma forma de recuperar defasagens quanto de potencializar a capacitação do futuro docente. Assim, se concebemos a universidade como um espaço de democratização da cultura, aproximar leitores de livros é uma das formas de executar essa democracia. No mesmo sentido, demonstrar aos futuros professores como usufruir da potência da dimensão humanizadora da literatura em sala de aula é apostar que, em suas futuras práticas, eles prezarão por explorar também esta dimensão dos textos literários tão usados como pretexto para o ensino de conteúdos.

Como proposta metodológica o letramento literário vai muito além dos círculos de leitura e dos diários de leitura, oferecendo um arcabouço de inúmeras outras atividades que se ajustam aos mais diferentes anos do ensino fundamental e médio e que se abrem para as mais diversas possibilidades de recriação. As duas exploradas nessa experiência foram aquelas que os professores estagiário e regente julgaram poder funcionar melhor para o ensino superior e demonstraram-se, realmente, potentes no contexto em questão.

Revista Interinstitucional Artes de Educar. Rio de Janeiro, V. 6, N.2- pág. 692-712 maio-agosto de 2020: "Bebês e crianças: cultura, linguagem e políticas"

DOI: 10.12957/riae.2020.44629 


\section{REFERÊNCIAS}

AMADO, Jorge. Capitães da Areia. $1^{\mathrm{a}}$ ed., $36^{\mathrm{a}}$ reimpressão. São Paulo: Companhia das Letras, 2011.

CANDIDO, Antonio. A literatura e a formação do homem. In: CANDIDO, Antonio. Textos de intervenção. São Paulo: Editora 34, 2002.

CANDIDO, Antonio. O direito à literatura. In: CANDIDO, Antonio. Vários escritos. Rio de Janeiro: Ouro sobre Azul, 2011.

COLOMER, Teresa. Andar entre livros: a leitura literária na escola. $1^{a}$ ed. São Paulo: Global, 2007.

COSSON, Rildo. Letramento literário: teoria e prática. $2^{\mathrm{a}}$ ed, $7^{\mathrm{a}}$ reimpressão. São Paulo: Contexto, 2018.

Círculos de leitura e letramento literário. $1^{\mathrm{a}}$ ed, $2^{\mathrm{a}}$ reimpressão. São Paulo, $2018 \mathrm{~b}$.

JESUS, Carolina Maria de. Quarto de despejo: diário de uma favelada. 10a ed. São Paulo: Ática, 2013.

KRAMER, Sonia, JOBIM E SOUZA, Solange. Histórias de professores: leitura, escrita e pesquisa em educação. $1^{a}$ ed. São Paulo: Ática, 1996.

MEIRA, Caio. Apresentação à edição brasileira. In: TODOROV, Tzvetan. A Literatura em Perigo. Trad. Caio Meira. 5 ${ }^{\mathrm{a}}$ ed. Rio de Janeiro: DIFEL, 2014.

PAULINO, Graça; COSSON, Rildo. Letramento literário: para viver a literatura dentro e fora da escola. In: RÖSING, Tânia Maria Kuchenbecker; ZILBERMAN, Regina (Orgs). Escola e leitura: velha crise, novas alternativas. São Paulo: Global, 2009.

SEGABINAZI, Daniela Maria; SILVA, Raquel Souza da. O ensino de literatura continua em perigo. Revista Língua e Literatura, Frederico Westphalen, v. 17, n. 30, 2015. ISSN 1984-381X. Disponível em: http://www.ufpb.br/geef/contents/documentos/publicacoes/o-ensino-deliteratura-continua-em-perigo-revista-lingua-literatura.pdf. >. Acesso em: 20 de jul. 2019.

SOARES, Magda Becker. Letramento: um tema em três gêneros. $1^{\text {a }}$ ed. Belo Horizonte: Autêntica, 1998.

TODOROV, Tzvetan. A Literatura em Perigo. Trad. Caio Meira. $5^{\text {a }}$ ed. Rio de Janeiro: DIFEL, 2014.

Revista Interinstitucional Artes de Educar. Rio de Janeiro, V. 6, N.2- pág. 692-712 maio-agosto de 2020: "Bebês e crianças: cultura, linguagem e políticas"

DOI: $10.12957 /$ riae.2020.44629 
VASCONSELOS, José Mauro de. O meu pé de laranja lima. $4^{\text {a }}$ ed. São Paulo: Melhoramentos, 2018.

YUNES, Eliana. Pelo avesso: a leitura e o leitor. Revista Letras, Curitiba, v. 44, 1995. ISSN

2236-0999 Disponível em: https://revistas.ufpr.br/letras/article/view/19078/12383 Acesso em: 20 de jul de 2019.

${ }^{\text {i } L i c e n c i a d o ~ e m ~ L e t r a s ~-~ L i ́ n g u a ~ P o r t u g u e s a ~ e ~ R e s p e c t i v a s ~ L i t e r a t u r a s ~(U n i p a m p a ~-~ C a m p u s ~ B a g e ́), ~ p o s s u i ~ t i ́ t u l o ~ d e ~}$ Especialista em Linguagens Verbais e Visuais e Suas Tecnologias (IFSul - campus Pelotas), é Mestre em Educação

Revista Interinstitucional Artes de Educar. Rio de Janeiro, V. 6, N.2-pág. 692-712 maio-agosto de 2020: "Bebês e crianças: cultura, linguagem e políticas"

DOI: $10.12957 /$ riae.2020.44629 
(UFPEL) e doutorando em Letras - Estudos Literários (UFSM). E-mail: juuniorferreira@ yahoo.com.br Caçapava do Sul/RS. ORCID: http://orcid.org/0000-0002-4182-1070

ii Hisales - História da Alfabetização, Leitura, Escrita e dos Livros Escolares - é um centro de memória e de pesquisa vinculado ao Programa de Pós-Graduação em Educação (PPGE) da Faculdade de Educação (FaE) da Universidade Federal de Pelotas (UFPel). Coordenado pelas professoras Eliane Peres e Vania Grim Thies, reúne pesquisadores da UFPel e de outras instituições de ensino da região sul, e tem procurado estabelecer uma política de recolha, tratamento e guarda de objetos da cultura escolar, constituindo, assim, importantes acervos para a manutenção da história e da memória da alfabetização e para a pesquisa educacional. Mais informações a respeito do Hisales podem ser vistas via internet, no site (http://www.ufpel.edu.br/fae/hisales/) e no perfil na rede social Facebook (Hisales). 